\title{
Study the Effective Factors on Brand equity (Case Study in Bank Sepah- East Tehran Province Branch)
}

\author{
Alireza Mikaeili ${ }^{1}$, Mahshid Moshiri Langeroudi ${ }^{2}$, Mehrnoush Seraj ${ }^{2}$, Elnaz Sharif ${ }^{2}$, \\ Hamidreza Aria ${ }^{2}$
}

Received:20.08.2015

Revised:25.09.2015

Accepted: 30.09.2015

\begin{abstract}
The present research studies the relation between the brand equity of Bank Sepah Brand and its customers' satisfaction. The present research poses this question as "what relation exists between equity of Bank Sepah brand and its customers' satisfaction?" To answer this question, 385 questionnaires were distributed among the employees of Bank Sepah- selected by random sampling, East Region of Tehran in September 2015 to January 2016. Ultimately, 60 questionnaires were analyzed by SPSS. The results showed that correlation between the two major variables of the research is significant in 0.01 equal to 0.646 . Due to its positive value, the main hypothesis of the research was approved. Therefore, it could be concluded that there is a direct and significant relationship between the two major variables of the research. In another word, in case of increase in the equity of Bank Sepah Brand, the amount of its customers' satisfaction will be increased. The descriptive statistic of the research reveals that the prioritization of customers' satisfaction dimensions includes; in order, the criteria of supporting the customer, moral and relations, actual quality of the product, environment and costs. In addition, prioritization of the dimensions of equity of brand includes- in the order- criteria of brand awareness, the perceived quality, loyalty to brand and the brand association. In the meantime, all secondary hypotheses of the research on Bank Sepah were confirmed. The findings on demographic characteristics of the research with the dimensions of customer's satisfaction and the brand equity are also considerable. The results from regression table reports $R^{2}$ equal to 0.380 ; meaning that linear regression of brand association, loyalty to brand, knowledge on the brand and the perceived quality justify around $38 \%$ of total changes in customer's satisfaction all in integrity and the residual is the share of other variables.
\end{abstract}

\section{Keywords: Brand equity, Customer's Satisfaction, Loyalty to Brand, Perceived Quality, Brand awareness}

\section{Introduction}

Today, banking industry in any region and country is facing an intensive competition. Due to this global competition, banks are seeking global expansion and follow global branding strategy (Robinson, 2007). These issues have created many changes in banking industry structure (Debling, 2009, Harris, 2002, Howcroft \& Durkin (2003), McDonald et al. (2001), Milligan (1995). These structural changes have made financial service organizations to establish strong brands for themselves (Devlin \& Azhar 2004) , create distinctions and focus on the internal and external relations of their organizations (Devlin, Sounders \& Watters, 1993); therefore, establishing brand in a highly competitive in financial atmosphere of today world seems inevitable (Debling, 1998, Haris, 2002).

Furthermore, due to the intangible feature and other characteristics of services, as well as its complex presentation, branding is highly

\section{Author's Address}

\footnotetext{
${ }^{1}$ Human Resources, Semnan University

${ }^{2}$ Marketing Major, I.A.U. Firouzkouh Branch
}

critical for services (Berry 2000, de Chernatony \& Dall'Olma Riley 1999, Dibb \& Simkin 1993); and it is anticipated to play an important role in financial services marketing (Devlin, 1998). Due to some reasons, financial services have their specific challenges; as in general state, financial services brands have slight significance and sensational demand (De Chematony \& Dall' Olma Reily 1999, Delvin \& Azhar, 2004, McDonald et al, 2001, Jones, 1999). In addition, Diparnatory \& Cotam, 2005) claim that financial services providers traditionally show little importance to their brands and those who have already done that have slightly moved away from their logo and the visual brand of their brand elements. Devlin (1998) claims that successful branding of financial services is challenging and achieving the equity of a proper brand in financial markets are difficult for branding managers.

In the competitive, complicated and dynamic atmosphere of banking system, the smallest difference in providing services leads to gigantic transactions in the industry. Traditional banks largely turn into customer-core banks and in this 
approach; too, they do this in accordance of the relation-based marketing principles and fundamentals that aim at customer loyalty as their main target. In this dynamic environment, establishing and implementing strategies that would lead to customers' loyalty is of significant importance (Beerli \& et al), 2004, 253).

\section{Expression of research problem}

With no doubt, Bank Sepah is considered as one of the most important icons and symbols of an authority holder bank in a market; for, the main output of their performance will be achievement to security, stability and peace of a market. Brand (trade name and mark) is of the important and iconic criteria in the scope of Bank Sepah activities that could be effective in the satisfaction. Professor Philip Cutler believes that brand is a permanent commitment of a seller in presenting a series of characteristics, advantages and specific services. In present research, one of the brand fundamentals has been considered as the equity; thus, the problem in the present research is low satisfaction of Bank Sepah customers; and in line with its study, the partial issue of the research is whether or not there is a relationship between low satisfaction of Bank Sepah customers and the equity of its trading mark and brand. Therefore, we aimed at evaluating the effects of the equity of trading mark and name of Bank Sepah on its customers' satisfaction; and if necessary, present applied approaches for promoting customers' satisfaction.

\section{Literature review of the research}

Customer's satisfaction: With no doubt, customer's satisfaction is a highly strategic subject in the recent decade. Now, as customers decide the company's sustainment in the global economy; they too, should aim all their activities and capabilities at customers' satisfaction; for, customers are the only source of capital return. Thus, the first principle in today world business is to create customer- desired values (Hill, 2006: 11). For this reason, customer-orientation has been recognized as the milestone of modern marketing management theories. In fact, the extensive efforts and works which are shown by researchers, experts and managers of trading enterprises in promoting the performance management tools and improving its vision, indicate that presently, customer's satisfaction is considered as one of the most important factors in determining the success of enterprises in trading and profitability (Kordnanich, 2003: 6). An organization is customer-centered when it can earn its customer's satisfaction by providing precise, fast and with no waste of time services (Karimian 2003: 3). Managers in production and service institutes in all governmental, public, cooperative and private sectors gradually find out that it is not mere quality of products that would distinguish them from others; rather, the focus must be shifted from market-centered to customer-centered approach. So far, many of them not only have already shifted their focus from market to customer; but also, they view maintaining and saving their present customers as a less expensive, feasible and perhaps more profitable and attractive strategy (Horowitz, 2001: 11). In the intensive competitive atmosphere, failure in customer-orientation and neglecting customers' demands and anticipations causes the death and destruction of organization. Most markets are highly competitively and enterprises need to produce goods and present services that earn customer's satisfaction and subsequently his/its loyalty in order to survive (Hosseini et al, 2003: 49). Customer's satisfaction is the customer's feeling or attitude towards the product or service. The satisfaction expressed by the customer is the main outcome of marketer's activities which serves as a connecting bridge between various stages of purchasing behavior of the consumer. If customers feel satisfied by receiving specific services or products, they will perhaps repeat their purchase. The satisfied customers probably share their desirable trades with other people and the result of those dialogues would serve as a positive mouth to mouth advertisement for the enterprise, organization and entity; or vise versa (Cordnaij, 2003: 6). Customer's satisfaction is highly important, as according to American Association of Consumers, finding new customer is five times more costly than keeping the customer (Hill 2009: 15). Different definitions have been introduced by marketing theorists. Cutler defines customer's satisfaction as a degree of fulfilling customer's anticipation by actual performance of a company. In Cutler's view, if company's performance fulfils customer's satisfaction, the customer will feel satisfaction; otherwise, he feels unsatisfied. In a simple definition, it could be said that customer's satisfaction is his feeling or attitude towards the product or service (Cordnaij 2003: 6). Jamal and 
Nasser define customer's satisfaction as the customer's feeling or view on a product or service after using that product or service. These two researchers explain that customer's satisfaction is the main result of marketer's activities and acts as a connecting factor between different stages of consumer's purchasing behavior. For example, if the customers are happy with a specific service, they are most likely trend to repeat the purchase. Satisfied customers perhaps speak about their experiences and subsequently, they are engaged in a positive mouth to mouth (oral-verbal) advertisement. On the contrary, unsatisfied customers probably discontinue their relation with the company are become engaged in negative oral- verbal propaganda. In addition, behaviors such as repeating the purchase and oral-verbal advertisement directly affect the survival and profitability of a company (Jamal and Nasser 2002: 147). Blanchard and Galovey believe that customer's satisfaction is the consequence of customer's perception in the course of a transaction or value relation when the price is equal to the ratio of quality of services provided to the price and customer's costs (Hallowell 1996: 28). A definition on customer's satisfaction which is agreed by most researchers is that customer's satisfactions the outcome of a comparison made by the customer before purchase on the anticipated performance and actual performance which is perceived and the cost which is paid. (Berlli et al, 2004: 256). In general, customer's satisfaction means customer's perception and feeing which is fulfilled by supplier or even has gone beyond it (Hill 2006: 16). Researches show that many organizations do poorly on their personnel in expressing the importance of improving services provided to customers. Developing a certain level of motivation in the employees could be realized only through senior management's commitment on measuring customer's satisfaction, setting specific goals and providing rewards for the employees (Ibid, 32). Large institutes and companies have already conducted researches on knowing the situation of customer's satisfaction. In line with measuring customer's satisfaction, Pittsburg Software Company has considered the ten-criteria measures as follows: product, subjects on improving the product, the subjects of legal maintenance, customer support, software problems, installation support, consultation, management, customer's training, general (ibid: 285). The AT Group of this institute which is active in producing electric gears, measurement tools, water disinfection facilities and telescope security system include: safety, quality, on time delivery, technical support, relations, documentation, money value, reaction to changes, price, after sale services, reaction to the demand, project management, project commencement, assurance quality, account control and a vast range of service provision (Ibid: 321). ABC: This company has used ten criteria as follows in its researches: on time delivery, quality of goods, teaching operation of the product, acceleration in answering the questions and problems, technical support by service centers of the company, technical support in place by the company, sale services of relevant items, company's ability in innovation, price and leadership ability (Hill 2009: 181). The Servqual model was introduced by three university professors, Parasurman, Zeithaml and Berry in 1980 to measure customers' perception on the quality of services. They introduced the five dimensions of quality of services as follows: 1Tangibles: They include physical equipment, facilities and employees' appearances. 2Reliability: The ability to perform the committed services in full confidence and care. 3Responsiveness: This includes willingness to help customers and immediate provision of services. 4- Guaranty: That includes employees' knowledge and manner and their ability in conveying confidence and trust. 5- Sympathy: This includes empathy and specific attention the company provides for its customers (Hill 2006: 323). The model which is employed in the present research is in fact developed by including and combining the above-mentioned models, receiving the views of the relevant experts, and the conditions and situations of Bank Sepah chain stores, consisting of the five dimensions of actual quality of the product, environment, morality and relationship of costs and supports

Brand equity: Various and different definitions have been introduced on the concept of brand. Among these definitions, some are as follows: Brand is the constant commitment of a seller in providing a series of characteristics, advantages and services for the buyers (Cutler 2006: 56). Oliver (1993) quoting Stephen King states that a consignment is an item which is made in a factor; however, brand is something which is bought by a customer. Brand means any design, sound, 
feature, color or a combination of these which is used to create distinction between the products and services of a producer or seller, and the products and services of competitors (Cutler 2004: 114). The American Marketing Association (AMA) in 1960 defines brand as a name, mark, logo or design or a combination of them which serve to identify the goods and services provided by a seller or a group of sellers and disguising those goods and services from competitors' products. Value is one of the sixmeaning of brand which states brand reveals a subject on the values of producing companies (Cutler 2008: 356). Crosno et al (2009) brand equity emerges from elements such as brand association, awareness of brand, the implied quality, loyalty to brand and other proprietorship assets. David Aaker (1991) introduces five elements for brand equity that includes brand knowledge, loyalty to brand, perceived quality, brand association and specific assets Farquhar (1989) believes that brand equity is an added value that the brand gives to a product. Keller (1998) claims that brand equity is a distinctive effect on brand knowledge (knowledge, implications or inferences) on consumer's reaction. According to Professor David Aaker, brand equity roots in the four categories introduced in this model:

1-Brand awareness: Brand awareness is the capability of potential buyer in recognizing or remembering that the brand belongs to a specific class of product. If the brand is the first name that is remembered, that name is the superior name in term of awareness.

2-Perceived quality of services: Boulding et al (1993) defined this criteria as the consumer's awareness of the superior quality of this product than other products. In another word, customer's perception of the general quality or superiority of a good or service towards customer's trend to replace it. Zeithmal and Bitner (1996) also state that the perceived quality is not the actual quality of the product, rather it is the mental evaluation of the consumer on that product.

3-Brand loyalty: In view of American Marketing Association, brand loyalty is an advantage when a customer instead of buying a product from several suppliers, buys it frequently from a single supplier.

4- Brand association or brand association: In Crosno et al (2009) view, these criteria is a reflection of mental association and deep attitudes of the consumer on a brand. In Aaker's view, anything which is related to the brand in memory defines the brand association. Brand association is any aspect related to the brand in mind and could include consumer's mentality, characteristics of the product, consumption cases, associations related to the organization, brand personality and symbols. The clarity of the variables which are defined as ease in measuring the variables, extensive use of model in research studies and high frequencies of using questionnaire in different markets and are among the most important strong points in Aaker's model. It should be mentioned that the before said model is the main core of research in brand equity scope.

\section{Goal of research}

As the brand equity is the independent variable in this research and customers' satisfaction is the dependent variable, the main goal in this research is to study the relationship between Bank Sepah brand equity and its customers' satisfaction.

\section{Conceptual model of $t$ he research}

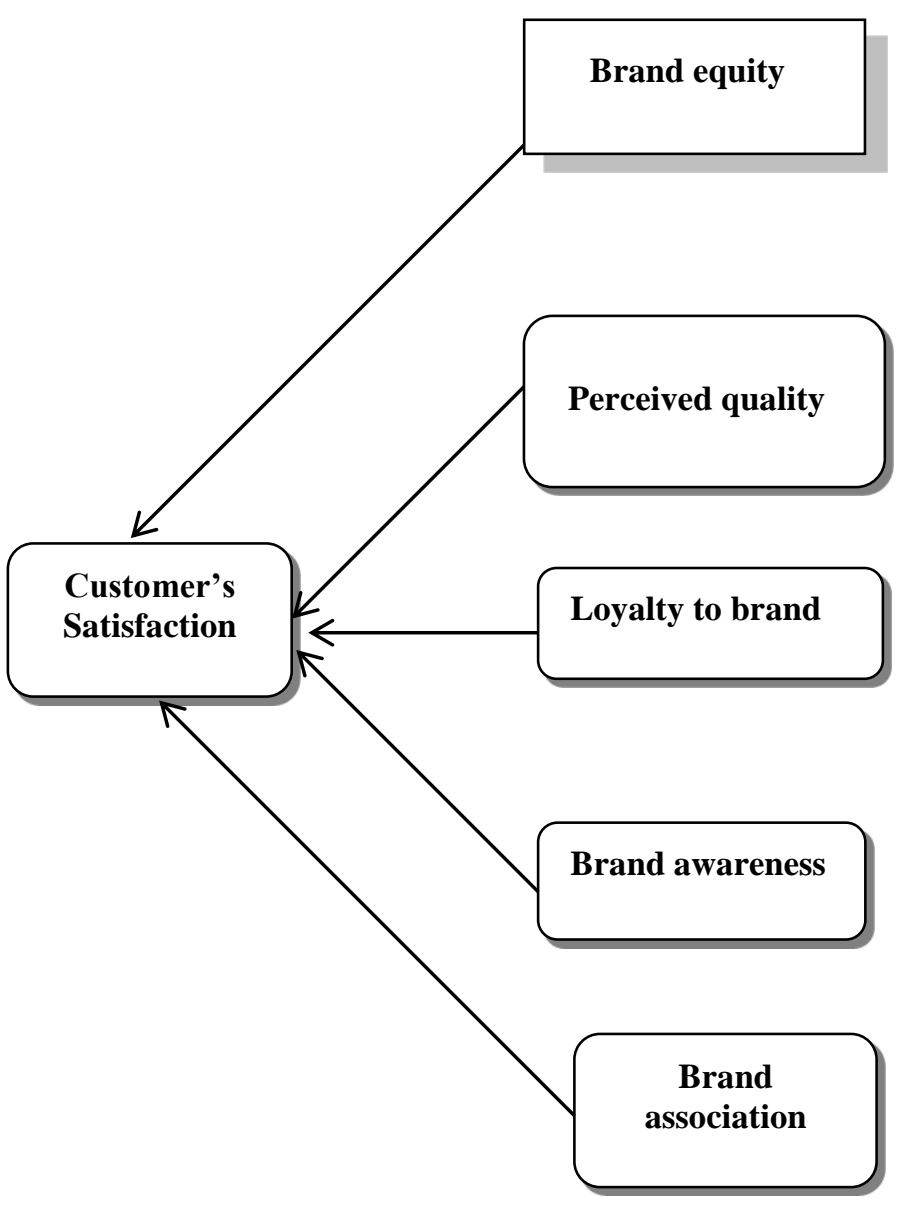




\section{Research hypotheses}

With respect to the goals and anticipated results, and based on the model presented on customer's satisfaction and brand equity, the main hypothesis of the research is a direction free relation (two scopes) which is stated as "there is a relationship between the dimensions of brand equity of Bank Sepah and its customers' satisfaction".

In addition, the secondary (minor) hypotheses are:

1) There is a relationship between brand association of Bank Sepah and its customers' satisfaction.

2) There is a relationship between brand awareness of Bank Sepah and its customers' satisfaction.

3) There is a relationship between brand loyalty of Bank Sepah and its customers' satisfaction.

4) There is a relationship between perceived quality of Bank Sepah brad and its customers' satisfaction.

5) There is a relationship between actual quality of product and brand equity of Bank Sepah.

6) There is a relationship between the environment and brand equity of Bank Sepah.

7) There is a relationship between personnel's conduct and relationship, and the equity brand of Bank Sepah.

8) There is a relationship between the cost and brand equity of bank Sepah.

9) There is a relationship between supporting the customer and brand equity of Bank Sepah.

\section{Research methodology}

In terms of goal, the present research is applied, in terms of data collecting time, it is survey and in terms of method of collecting data and information, this research is a field study. The core models of the research in the scope of brand equity include Professor David Aaker's model on brand equity and in customer's satisfaction scope, it uses an author-based model which has been developed by literature review and obtaining the experts' views. In this regards, a questionnaire consisting both scopes was developed by using the five-option Lickert combined scale (completely disagree, relatively disagree, not disagree not agreed, relatively agree and totally agree) to measure the existing status. Of course, the final scale for data analysis was the distance scale. It should be mentioned that the questionnaire was developed in template of 29 questions and 9 dimensions (five dimensions on customer's satisfaction and four dimensions on brand equity). The validity of the test in the research was checked by benefitting from the viewpoints and guidance's of experts who studied the question. Thus, the measurement tool of the research has content validity and contains face validity as well. Since Cronbach Alpha Model is one of the most important and most frequently method which is used in reliability calculations, the Statistical Processor for Social Science (SPSS), this method was used to obtain the reliability. 36 approved questionnaires were divided among statistical population. The Cronbach Alpha coefficient in the research was reported to be 0.866 . Based on rule of thumb, since the coefficient which is obtained is less than 0.9 and more than 0.8 , it could be interpreted that the reliability of questionnaire structures is somewhere between excellent and good. In general, the reliability of measurement tool is high. The statistical population of the research consisted of employees of Bank Sepah in East zone of Tehran and a sample was taken from them by employing random sampling method. The volume of the sample was obtained by following relation:

$$
n=\frac{t^{2} p q}{d^{2}}=\frac{(1.96)^{2}(0.5)(0.5)}{(0.05)^{2}}=\frac{0.9604}{0.0025}=384
$$

$$
\begin{aligned}
& d=0.05 \\
& t=1.96 \\
& p=0.5 \\
& q=0.5
\end{aligned}
$$

Thus, with respect to the above formula, the volume of the sample is 384 . For this purpose, 384 questionnaires were distributed among the employees of Bank Sepah and ultimately, 60 questionnaires were put in access of researchers for final analysis. Finally, the data collected through questionnaire distribution has been analyzed by using SPSS software. 


\section{Findings of the research}

In line with data analysis, first the descriptive statistics of the research has been studied; thus, the demographic characteristics of the statistics population of the research are listed in table number 1 .

\section{Table 1- Specifications and characteristics of statistical samples}

\begin{tabular}{|c|c|c|c|c|c|c|c|}
\hline \multicolumn{2}{|c|}{ Description } & Number & Percent & \multicolumn{2}{|l|}{ Description } & Number & percent \\
\hline \multirow[t]{2}{*}{ Gender } & Female & 270 & 45 & \multirow{4}{*}{$\begin{array}{l}\text { Employment } \\
\text { records }\end{array}$} & -3 years & 101 & 16.8 \\
\hline & Male & 330 & 55 & & $3-5$ years & 163 & 27.2 \\
\hline \multirow[t]{4}{*}{ Age } & -30 years & 123 & 20.5 & & +10 years & 221 & 36.8 \\
\hline & $\begin{array}{l}30-40 \\
\text { years }\end{array}$ & 158 & 26.3 & & High school & 115 & 19.2 \\
\hline & $\begin{array}{l}40-50 \\
\text { years }\end{array}$ & 215 & 35.8 & \multirow[t]{4}{*}{ education } & $\begin{array}{l}\text { High school } \\
\text { diploma }\end{array}$ & 48 & 8 \\
\hline & $\begin{array}{ll}+ & 50 \\
\text { years } & \end{array}$ & 104 & 17.4 & & A.D. & 153 & 25.5 \\
\hline & & & & & B.S./BA. & & 42.9 \\
\hline & & & & & Graduate & & 236 \\
\hline
\end{tabular}

Table number 2 shows that among the dimensions of customer's satisfaction, the criteria of supporting the customer has highest mean with 19.884 value, the criteria of ethics and relation, with 19.0588 is in the second rank, and the criteria of actual quality of the product, environment and costs had highest means; respectively. Among the dimensions of equity of the brand; too, the criteria of brand awareness with 22.0114 mean and the criteria of perceived quality, loyalty in brand and brand association had highest means; respectively

Table number 2: Descriptive statistics of research variables

\begin{tabular}{|l|l|l|l|l|l|l|}
\hline Variables & Range & Minimum & Maximum & Mean & Criteria deviation & Variance \\
\hline Brand equity & 2.60 & 2.20 & 4.80 & 3.58 & 072 & 0.53 \\
\hline Honesty of brand characteristics & 2.45 & 2.27 & 4.73 & 3.77 & 0.75 & 0.56 \\
\hline Passion of brand characteristics & 2.91 & 2.09 & 5 & 3.66 & 078 & 0.62 \\
\hline Merit of brand characteristics & 3.75 & 1.25 & 5 & 3.54 & 09 & 0.81 \\
\hline Perfection of brand characteristics & 2.88 & 2.13 & 5 & 3.57 & 0.68 & 0.46 \\
\hline Hostility of brand characteristics & 3.60 & 1.40 & 5 & 3.51 & 0.94 & 0.88 \\
\hline
\end{tabular}

Since the scale which is used in this research is distance type, to test the research hypothesis and evaluation of correlation among variables, the Pierson linear correlation test and SPSS 16 software were used. Table number 3 shows the correlation coefficient between the dimensions of customers' satisfaction and the brand equity as Pierson correlation coefficient. With respect to the results of this table, there is a positive significant relationship between most dimensions of customer's satisfaction and the equity of the brand.

Table number 3: Results of Pierson correlation coefficient between minor variables of the research

\begin{tabular}{|l|l|l|l|l|l|l|}
\hline Factors & $(1)$ & $(2)$ & $(3)$ & $(4)$ & $(5)$ & $(6)$ \\
\hline Honesty of brand characteristics (1) & 1 & & & & & \\
\hline Passion of brand characteristics (2) & $0.51^{*}$ & 1 & & & & \\
\hline Merit of brand characteristics (3) & $0,61^{* *}$ & $0.54^{*}$ & 1 & & & \\
\hline Perfection of brand characteristics (4) & $0.74^{* *}$ & $0.66^{* *}$ & $0.54^{*}$ & 1 & & \\
\hline Hostility of brand characteristics (5) & $0.48^{*}$ & $0.55^{*}$ & $0.44^{*}$ & $0.34^{*}$ & 1 & \\
\hline Equity of the brand (6) & $0.68^{* *}$ & $0.64^{* *}$ & $0.74^{*}$ & $0.67^{* *}$ & $0.34^{*}$ & 1 \\
\hline
\end{tabular}


The direction of assessing the correlation between demographic characteristics (as independent variable) and the dimension of customer's satisfaction (as dependent variable), Spearman correlation coefficient has been used. Table number 4 shows the correlation coefficient between the customer's satisfaction and demographic characteristics dimensions. The results show that in general, there is a correlation between the variables of customer's satisfaction, and the age and amount of the service record.

Table number 4- The amount of correlation coefficient between the dimensions of customer's satisfaction and demographic specifications of respondents

\begin{tabular}{|c|c|c|c|c|c|}
\hline & & Gender & Age & Job records & education \\
\hline Brand equity & $\begin{array}{c}\text { Spearman correlation } \\
\text { coefficient }\end{array}$ & 0.078 & 0.21 & 0.18 & 0.19 \\
\cline { 2 - 6 } & Significance level & 0.68 & 0.25 & 0.32 & 0.31 \\
\cline { 2 - 6 } & Number & 30 & 30 & 30 & 30 \\
\hline
\end{tabular}

**Relationship is significant in 001 level (two scopes)

*Relationship is significant in 0.05 level (two scope

The results of simple linear regression, the independent and dependent variables by using enter method are as follows. Table number 6 reports the value of multiple correlation coefficients as 0.617 ; thus, there is a strong correlation between the independent and dependent variables. The amount of adjusted $R$ square is reported as 0.373 . This means that the dimensions of brand equity (brand association, loyalty to brand, knowledge on the brand and the perceived quality) define around $38 \%$ of total dependent variable variance alone (customer's satisfaction) and the remaining changes are affected by variables beyond the model.

Table number 5- Summary of statistics related to model Fit

\begin{tabular}{|c|c|c|c|c|}
\hline model & $\begin{array}{c}\text { Multiple } \\
\text { correlation } \\
\text { coefficient }\end{array}$ & $\begin{array}{c}\text { Defined } \\
\text { coefficient }\end{array}$ & $\begin{array}{c}\text { Adjusted R } \\
\text { Square }\end{array}$ & Standard \\
\hline 1 & $.755^{\mathrm{a}}$ & 0.570 & .481 & .52493 \\
\hline
\end{tabular}

Table number 7 shows the results of variance analysis. This table lists the source of changes in independent variable (customer's satisfaction) in the two sources of regression and residual and the sum of squares, freedom degree and mean squares are provided for each one of those sources.

Table number 6- Results of variance analysis

\begin{tabular}{|c|c|c|c|c|c|c|}
\hline Model & & $\begin{array}{c}\text { Sum of } \\
\text { squares }\end{array}$ & $\begin{array}{c}\text { Freedom } \\
\text { degree }\end{array}$ & $\begin{array}{c}\text { Mean } \\
\text { squares }\end{array}$ & $\begin{array}{c}\text { Fisher } \\
\text { statistics }\end{array}$ & $\begin{array}{c}\text { Significance } \\
\text { level }\end{array}$ \\
\hline \multirow{2}{*}{1} & Regression & 8.775 & 5 & 1.755 & \multirow{3}{*}{6.369} & \multirow{2}{*}{$.001^{\mathrm{a}}$} \\
\cline { 2 - 5 } & Residual & 6.613 & 24 & .276 & & \\
\cline { 2 - 5 } & total & 15.388 & 29 & & & \\
\hline
\end{tabular}

Table number 8 lists the results of regression effects coefficients in the two forms of standardized coefficients (Beta 2) and unstandardized coefficients (B). The unstandardized coefficients are the coefficients related to the estimated regression model. In the present research, the evaluated models include: The factors effective on the brand equity ( 0.646 $+51.869)=$ Equity of the brand.
The standardized coefficients are used for determining the relative share of each independent variable in defining the changes of dependent variables. The regression model evaluated based on standardized coefficients is as follows:

\subsection{6 (brand equity $)=$ customer's satisfaction}


Mikaeili et al.

Table number 7: Results on the coefficient of regression effects

\begin{tabular}{|l|c|c|c|c|c|}
\hline \multirow{2}{*}{ Model } & $\begin{array}{c}\text { Unstandardized } \\
\text { coefficients }\end{array}$ & \multicolumn{2}{|c|}{ Standardized coefficient } & Value (t) & \multirow{2}{*}{$\begin{array}{c}\text { Significant } \\
\text { level }\end{array}$} \\
\cline { 2 - 4 } & $\mathrm{B}$ & $\begin{array}{c}\text { Standard } \\
\text { error }\end{array}$ & Beta & .754 & .458 \\
\hline \multicolumn{1}{|c|}{ Fixed value } & .706 & .936 & & 3.232 & .004 \\
\hline $\begin{array}{l}\text { Honesty of brand } \\
\text { characteristics }\end{array}$ & .445 & .138 & .460 & -.582 & .566 \\
\hline $\begin{array}{l}\text { Passion of brand } \\
\text { characteristics }\end{array}$ & -.074 & .128 & -.081 & -3.720 & .001 \\
\hline $\begin{array}{l}\text { Merit of brand } \\
\text { characteristics }\end{array}$ & -.824 & .221 & -1.019 & 3.049 & .006 \\
\hline $\begin{array}{l}\text { Perfection of } \\
\text { brand } \\
\text { characteristics }\end{array}$ & .486 & .159 & .456 & 3.754 & .001 \\
\hline $\begin{array}{l}\text { Hostility of brand } \\
\text { characteristics }\end{array}$ & .775 & .206 & 1.001 & \\
\hline
\end{tabular}

The results of Freedman test have been used for comparing the mean of a number of

dependent population, as listed in table number 9 .

Table number 8. Descriptive statistic of Freedman Test

\begin{tabular}{|l|l|c|c|c|l|l|l|}
\hline & Mean & Criteria deviation & Minimum & Maximum & \multicolumn{3}{|c|}{ Percent } \\
\cline { 5 - 8 } & & & & & $25^{\text {th }}$ & $50^{\text {th }}$ & $75^{\text {th }} 1$ \\
\hline Actual quality & 3.6030 & .75325 & 2.27 & 4.73 & 2.9545 & 3.7727 & 4.2045 \\
\hline $\begin{array}{l}\text { Honesty of } \\
\text { brand } \\
\text { characteristics }\end{array}$ & 3.6606 & .78890 & 2.09 & 5.00 & 3.1136 & 3.9091 & 4.2727 \\
\hline $\begin{array}{l}\text { Passion of brand } \\
\text { characteristics }\end{array}$ & 3.5417 & .90099 & 1.25 & 5.00 & 3.0000 & 3.6875 & 4.2500 \\
\hline $\begin{array}{l}\text { Merit of brand } \\
\text { characteristics }\end{array}$ & 3.5750 & .68355 & 2.13 & 5.00 & 3.2188 & 3.5000 & 4.1250 \\
\hline $\begin{array}{l}\text { Perfection of } \\
\text { brand } \\
\text { characteristics }\end{array}$ & 3.5133 & .94055 & 1.40 & 5.00 & 2.9500 & 3.5000 & 4.2000 \\
\hline $\begin{array}{l}\text { Hostility of } \\
\text { brand } \\
\text { characteristics }\end{array}$ & 3.6030 & .75325 & 2.27 & 4.73 & 2.9545 & 3.7727 & 4.2045 \\
\hline
\end{tabular}

Table number 10 shows the mean scores of each one of the dimensions of dependent and independent variables by using Freedman test. As it shows, there is not much difference among the variables of customer's satisfaction; however, there is a high difference among variables among the dimensions of brand equity. The difference in the dimensions of brand awareness with other dimensions of equity of the brand is much more evident.

Table number 9: The results of Freedman variance analysis for the brand equity

\begin{tabular}{|l|c|}
\hline \multicolumn{1}{|c|}{ Factors } & Mean scores \\
\hline Honesty of brand characteristics & 3.13 \\
\hline Passion of brand characteristics & 3.20 \\
\hline Merit of brand characteristics & 2.77 \\
\hline Perfection of brand characteristics & 2.97 \\
\hline Hostility of brand characteristics & 2.93 \\
\hline
\end{tabular}


Table number 11 shows that the number of lines in each one of the 9 minor variables of the research (dimensions), which took value is equal to 331. This table also lists the amount of test stylistic, the freedom degree of test statistics and significance of the test. The results of Freedman variance analysis showed that the $\mathrm{Q}$ square test $\left(X^{2}=445.488\right.$ and $\left.d f=4\right)$ is significant and this analysis is acceptable.

Table number 11- Results of Q Square test

\begin{tabular}{|c|c|}
\hline Number & 30 \\
\hline Q square & 1.432 \\
\hline Freedom degree & 4 \\
\hline Asymp.Sig & .839 \\
\hline
\end{tabular}

\section{Conclusion}

In connection with the main hypothesis of the research on the existence of relationship between the dimensions of equity of Bank Sepah brand and its customers' satisfaction, the results showed that the correlation between these two variables in 0.01 significant level has been reported as 0.646 . With respect to the positive value, the main hypothesis of the research is approved. Thus, it could be concluded there is a direct and significant relationship between the two aforementioned variables. In another word, in case of increase in the equity of Bank Sepah brand, the degree of its customers' satisfaction will increase accordingly. The descriptive statistics of the research reveals that among the dimensions of customer's satisfaction, the criteria of supporting the customer has highest mean with 19.488 scores, the criteria of ethics and relations is in the second place by 19.0588 scores, and the criteria of actual quality of the product and costs expenses had the highest mean numbers; respectively. Among the dimensions of the brand equity; too, the criteria of brand awareness had highest mean number with 220114, and the criteria of the perceived quality, loyalty to brand and brand association; had highest mean values; respectively. By using the information in table number 3 , studies on the secondary hypothesis of the research, all minor hypotheses were approved. The findings resulted from the demographic characteristics of the research with the customers' satisfaction and the equity of the brand dimensions includes the followings:
1. There is a reverse correlation between the variables of environment and marital status of respondents (0.05 significance level). In another word, the single respondents evaluate Bank Sepah environments more positive.

2. There is a direct correlation (in 0.05 significance level) between the variables of environment and the service years of respondents. In another word, as service records of respondents are higher, the atmosphere of Bank Sepah is evaluated to be more positive

3. There is a direct correlation between the variables of the environment and respondents' age (0.01 significant level); in another word, as the respondents' age is higher, the atmosphere of Bank Sepah is evaluated more positive

4. There is a direct correlation between the variable of supporting the customers and the respondents' age (in 0.01 significance level). In another word, as the respondents' age is higher, the amount of supporting the customer in Bank Sepah is evaluated as higher.

5. There is a direct correlation between the variable of supporting customer and the service records of respondents (in 0.05 significance level). In another word, as the service records of respondents are higher, the degree of supporting customer in Bank Sepah is estimated as higher

6. In general, there is a direct correlation between the variable of customer's satisfaction and the service years of the respondents (in 0.05 significance level), that is, as the years of service of respondents are higher, satisfaction of Bank Sepah will be higher.

7. In general, there is a direct correlation between the variable of customer's satisfaction and the respondents' age (in 0.05 significance level). In another word, as the respondents' age is more, the satisfaction of Bank Sepah will be higher.

8. There is a reverse correlation between the variable of brand association and respondents' gender (in 0.05 significance level). In another word, the female respondents have higher implication on the brand of Bank Sepah.

9. There is a reverse correlation between the variables of the perceived quality and respondents' gender (in 0.05 significance level). In another word, female respondents had higher perceived quality on Bank Sepah brand.

The results of regression tables reported the modified determination coefficient as 0.373 ; that means that the linear regression of brand association, loyalty to brand, knowledge on the 
brand and the perceived quality justify around $38 \%$ of total changes in customers' satisfaction all by themselves and the residual is the share of other variables.

\section{Suggestions}

With respect to the analysis earned by the mentioned research, followings could be considered as applied suggestions:

1. Due to the existence of significant relationship between the dimensions of equity of Bank Sepah brand and its customers' satisfaction, it is obvious that the authorities must adopt more effective activities in the society on presenting Bank Sepah brand.

2. The results of analysis showed that Bank Sepah has high level in terms of customers' satisfaction dimensions, criteria of supporting the customer and ethics and relations criteria; however, on the criteria of actual quality of the product, environment and costs, it needs more efforts.

3. Among the aspects of brand equity, the criteria of knowledge on the brand had the highest score; however, the criteria of brand association had the least scores. More advertisement could be used on promoting the brand association.

4. Due to negative correlation between the variables of environment and marital status, it is necessary to provide a more suitable environment for the employees.

5. Due to the positive correlation between the variable of environment and respondents age, it is necessary to provide a more suitable atmosphere for meeting the needs of young generation

6. Due to the positive correlation between the variable of customer's satisfaction and respondents' age, it is necessary to adopt suitable measures for increasing the satisfaction of younger customers.

\section{References}

Hosseini, Seyed Hamid Khodadad and Asghar Pourfaz, Alireza and Azizi, Shahriar 2003. Identification and Prioritization of Effective Factors on the satisfaction of Iran Khodro Customers, Tehran, Payam Modiriat Journal, Volumes 7 \& 8.

Cutler, Philip 2006. Marketing Management, Bahman Forouzandeh, $4^{\text {th }}$ Ed. Isfahan, Amukhteh Publication
Cutler, Phillip 2004. Cutler in Market Management, Abdolreza Rezaeinejad, $3^{\text {rd }}$ Ed. Tehran, Fara Publication

Cutler, Philip 2008. Fundamentals of Marketing Management, translated by Dr. Ali Parsaian, $2^{\text {nd }}$ Ed. Tehran, Termeh Publication

Kordnaij, Asadollah 2003. Earning Customer's Satisfaction, the Most Important Challenge in Vehicles Industry, Tehran, Andisheh Gostar, SAIPA, Voo. 27-28.

Karimian Nokabari, Asghar 2003. Providing an Optimized Model of Service Providing to Bank Customers, by using Queue Models, Tehran, Graduation Thesis, Faculty of Management, Tehran Province

Horowitz, Jack 2001. Seven Keys of Services Strategy, translated by Seyed Mohammad Arabi and Davoud Izadi, Tehran, Office of Cultural Researches

Hill, Nigel and Self, Bill and Roche, George 2009. Measurement of Customer's Satisfaction, translated by Dr. Shahriar Azizi and Masoud Javdani, Tehran, Safar Publication

Hill, Nigel 2006. Measurement of Customer's Satisfaction, translated by Mohammadreza and Manizheh Eskandari, Tehran, Rasa Cultural Services Institute

Mohammadali Shah Hosseini, Amir Ekhlasi, Kamal Rahmani 2011. Equity of Services Brand and Purchase Behavior of Customers, $3^{\text {rd }}$ Ed. Tehran, Two Scientific- Research Journal on Modern Marketing Researches

Aker, D.A. 1991. Managing brand equity; capitalizing on the value of a brand name. The Free Press, New York, N.Y.

Beerli A, Martin J.D, Quintana A. 2004. "A model of customer loyalty in the retail banking market", European Journal of Marketing, Vol. 38, No. $1 / 2$, pp. 253-275.

Boulding, W. Karla, A. Staelin, R. And Zeithmal, V. 1993."A dynamic process model of service quality: from expectation to behavioral intentions ", Journal of Marketing Research, 30(Feb), pp. 7-27.

Crosno, J. Freling, T \& Skinner, S. 2009. "Does brand social power mean market might? Exploring the influence of brand social power on brand evaluation", Journal of Psychology \& Marketing, Vol.26 (2): 91-121. 


\section{Study the Effective Factors on Brand equity}

Farquhar, P 1989. "Marketing Brand Equity". Marketing Research, (Sep), PP.24 -33.

Hallowell, R. 1996. "The relationship of customer satisfaction, customer loyalty and profitability: an empirical study", International Journal of Service Industry Management, Vol. 7, No. 4, pp. 27-42.

Jamal, A. Nasser, K. 2002." Customer satisfaction and retail banking: an assessment of some of the key antecedents of customer satisfaction in retail banking", European Journal of Marketing, 20/4, pp. 146-160.

Keller, K. 1998. "Strategic brand management: building, measuring and brand equity", Prentice Hall: Englewood Cliffs, NJ.

Oliver, R, L. 1993. "Whence consumer loyalty". Journal of marketing.

Zeithmal and Bitner, M. 1996. "Services marketing", Mc Graw Hill, New York. 